\title{
Revisiting the Trapezius Flap as a Reconstructive Option for Cervico-Occipital and Thoracic Spine Regions
}

\author{
Ravikiran Naalla ${ }^{1}$ Vijay Murthy ${ }^{1} \quad$ Shashank Chauhan ${ }^{1} \quad$ Kavya Chinta $^{1} \quad$ Maneesh Singhal $^{1}$ \\ ${ }^{1}$ Department of Plastic, Reconstructive and Burns Surgery, All India \\ Address for correspondence Maneesh Singhal, MS, MCh, FRCS (Glasg), \\ Department of Plastic, Reconstructive and Burns Surgery, All India \\ Institute of Medical Sciences, Plastic Surgery Office, 5th floor, Teaching \\ Block, New Delhi 110029, India (e-mail: drmaneesh@gmail.com).
}

Indian J Plast Surg 2019;52:322-329

\begin{abstract}
Introduction Reconstruction of complex soft tissue defects around the cervicooccipital and thoracic spine regions is a challenging task. We want to share our experience with trapezius flap for the reconstruction of these complex cases.

Materials and Methods A retrospective analysis of patients who underwent reconstruction using trapezius flaps from January 2016 to June 2019 was performed. The indications, technique, complications, and outcomes were analyzed and presented.

Results Six patients (three males and three females, >10 years of age) underwent seven reconstructions using trapezius flaps (one of the patients underwent reconstruction using a bilateral trapezius flap). Trapezius flap was used to resurface the parieto-occipital $(n=2)$, cervico-occipital $(n=2)$, cervicothoracic $(n=1)$, and

Keywords

- trapezius flap

- cervical spine

- thoracic spine thoracic $(n=1)$ regions. All flaps showed successful outcomes; one patient had wound dehiscence, and one patient had partial skin graft loss.

Conclusion Trapezius flap is a reliable and good alternative to free flaps for the coverage of complex cervical-occipital and upper thoracic soft tissue defects.
\end{abstract}

\section{Introduction}

Wound complications following spinal and cranial surgeries are uncommon. ${ }^{1}$ However, factors such as surgical site infection, skin infiltration with tumor, and radiotherapy may lead to the destruction of local tissue and wound gaping. Though many of the cases can be managed with local wound care and skin grafting/local flaps, in some cases, soft tissue loss is significant. Local flap tissue is often inadequate to fill the three-dimensional soft tissue defects. The situation is more complicated when an implant is exposed in the wound bed.

Free flaps are generally preferred in the reconstructive ladder due to their versatility and reliability. ${ }^{2}$ Large soft tissues can be resurfaced with relatively less donor-site morbidity. However, it requires an extended duration of surgery, microsurgical expertise, and risk of total flap loss. Trapezius myocutaneous or muscle-only flap is an excellent regional option for resurfacing soft tissue defects over the cervico-occipital and complex posterior scalp regions.

Our study aims to share our experience with trapezius flap for the reconstruction of complex cervico-occipital and thoracic soft tissue defects.

\section{Materials and Methods}

A retrospective analysis of six patients aged over 10 years who underwent trapezius flap from January 2016 to May 2019 was performed. Patient's demographic data, the indication of surgery, complications, and outcomes were analyzed and tabulated ( - Table $\mathbf{1})$.

\section{Surgical Technique}

The anatomy of the trapezius muscle is well described. ${ }^{3}$ We prefer the prone position for the ease of dissection

\section{received}

June 19, 2019

accepted after revision

October 4, 2019

published online

December 26, 2019
DOI https://doi.org/

10.1055/s-0039-3400677

ISSN 0970-0358.
(C)2019 Association of Plastic

Surgeons of India

\section{License terms}

(요 (1) $\Theta \circledast$ 
Table 1 Details of the patients and flaps performed

\begin{tabular}{|c|c|c|c|c|c|c|}
\hline Case & Diagnosis & $\begin{array}{l}\text { Location of } \\
\text { defect }\end{array}$ & $\begin{array}{l}\text { Structure } \\
\text { exposed }\end{array}$ & $\begin{array}{l}\text { Flap } \\
\text { size } \\
(\mathrm{cm})\end{array}$ & Flap & Outcome \\
\hline 1 & $\begin{array}{l}\text { Cervical implant exposure following } \\
\text { resection of the craniovertebral } \\
\text { junction anomaly }\end{array}$ & $\begin{array}{l}\text { Occipitocervical } \\
\text { region }\end{array}$ & Cervical spine & $10 \times 6$ & Right LTMIF & $\begin{array}{l}100 \% \text { flap } \\
\text { survival }\end{array}$ \\
\hline 2 & $\begin{array}{l}\text { Cervical implant exposure following } \\
\text { resection of a C3-C } 4 \text { spinal intradural } \\
\text { extramedullary meningioma }\end{array}$ & $\begin{array}{l}\text { Occipitocervical } \\
\text { region }\end{array}$ & Cervical vertebra & $12 \times 9$ & Right LTMIF & $\begin{array}{l}100 \% \text { flap } \\
\text { survival }\end{array}$ \\
\hline 3 & $\begin{array}{l}\text { Implant exposure following correc- } \\
\text { tion of kyphoscoliosis }\end{array}$ & $\begin{array}{l}\text { Upper thoracic } \\
\text { region }\end{array}$ & $\begin{array}{l}\text { Thoracic spinal } \\
\text { implant }\end{array}$ & $8 \times 4$ & $\begin{array}{l}\text { Right trapezius } \\
\text { turnover flap }\end{array}$ & $\begin{array}{l}100 \% \text { flap } \\
\text { survival }\end{array}$ \\
\hline 4 & $\begin{array}{l}\text { Full-thickness scalp and } \\
\text { parieto-occipital calvarial defect } \\
\text { following excision of a tumor } \\
\text { involving the scalp and calvarium }\end{array}$ & $\begin{array}{l}\text { Parieto-occipital } \\
\text { region }\end{array}$ & $\begin{array}{l}\text { PMMA prosthesis } \\
\text { for calvarial defects }\end{array}$ & $17 \times 10$ & Right LTMIF & $\begin{array}{l}\text { Minor wound } \\
\text { dehiscence } \\
\text { leading to im- } \\
\text { plant exposure }\end{array}$ \\
\hline 5 & $\begin{array}{l}\text { Rhabdomyosarcoma over the nape } \\
\text { of the neck }\end{array}$ & $\begin{array}{l}\text { Lower neck and } \\
\text { upper thorax }\end{array}$ & $\begin{array}{l}\text { Lower cervical and } \\
\text { upper thoracic } \\
\text { spinous processes }\end{array}$ & $8 \times 5$ & $\begin{array}{l}\text { Right trapezius } \\
\text { turnover flap and } \\
\text { skin graft }\end{array}$ & $\begin{array}{l}\text { Partial skin } \\
\text { graft loss }\end{array}$ \\
\hline 6 & $\begin{array}{l}\text { Surgical site infection and wound } \\
\text { dehiscence leading to thoracic spinal } \\
\text { implant exposure }\end{array}$ & Thoracic spine & $\begin{array}{l}\text { Thoracic spinal } \\
\text { implant }\end{array}$ & $\begin{array}{l}15 \times 8 \\
30 \times 8\end{array}$ & $\begin{array}{l}\text { Left trapezius } \\
\text { myocutaneous } \\
\text { V-Y advancement, } \\
\text { right trapezius } \\
\text { myocutaneous } \\
\text { bipedicled flap in } \\
\text { addition to latissi- } \\
\text { mus dorsi flap }\end{array}$ & $\begin{array}{l}100 \% \text { flap } \\
\text { survival }\end{array}$ \\
\hline
\end{tabular}

Abbreviation: LTMIF, Lower trapezius myocutaneous island flap.

and inset. The outline of the trapezius muscle is marked between the external occipital protuberance superiorly, the spinous process of the 12 th thoracic vertebra inferiorly, the middorsal line medially, and a line connecting the acromion to the spinous process of the 12th thoracic vertebra laterally, as shown in - Fig. 1. The medial border and the tip of the scapula are also marked.

- Lower trapezius myocutaneous island flap (LTMIF): this flap was most often preferred for cervico-occipital defects. A template of the defect was made and planned in reverse to design the skin territory over the trapezius muscle. In a traditional LTMIF (based on the transverse cervical artery), a vertical orientation of the skin paddle is preferred. The skin paddle was designed over the muscle, and if the skin paddle crosses the muscle border, the crossed portion is considered as a random pattern flap (length-to-breadth ratio of $1: 1$ ). The pivot point is between the scapula and the midline at the level of the acromion process. However, when a large flap is required, a significant portion of the flap is designed inferior to T12. The incision is preferred at the lateral border of the skin paddle to ensure appropriate identification and preservation of the trapezius muscle with the skin paddle. The trapezius muscle is just beneath the fascia over the back and the muscle fibers are longitudinal in orientation, whereas rhomboids are underneath the trapezius muscle and horizontal in orientation. Once it was assured, the trapezius muscle was dissected all around, and the skin incision was extended superiorly two fingerbreadths lateral to the spinous processes. The trapezius muscle was dissected from the medial to lateral direction as we approach superiorly to the neck to visualize and include the transverse cervical vessels. As the dissection proceeds from the inferior to superior direction, rhomboid major and minor have to be identified and preserved. There is a difference of opinion regarding the inclusion of dorsal scapular vessels in large trapezius flaps, which is described in detail in the Discussion section. We have not included them in any of our patients. Inclusion of dorsal scapular vessels required intramuscular dissection through the rhomboids. The reach of the flap can be increased by islanding the myocutaneous flap and dissecting the transverse cervical vessels until its origin in the posterior triangle of the neck. Once the flap inset was made, the donor site was closed undercover a suction drain. Postoperatively patient is nursed in the lateral/prone position for 2 weeks.

- Turn over flap: this is a muscle-only flap. The flap is harvested by extending the preexisting cervicothoracic wound. The inferior half of the muscle flap is exposed after skin, and subcutaneous tissue is elevated. The muscle is dissected from the inferior to superior and the lateral to medial direction, as described previously, to preserve the descending branch of transverse cervical vessels. The spinal attachments of the trapezius muscle are released and is transferred to the defect by turning the inferior portion into the midline defect. This flap can also be based on the intercostal vessels after dividing the transverse cervical vessels. 

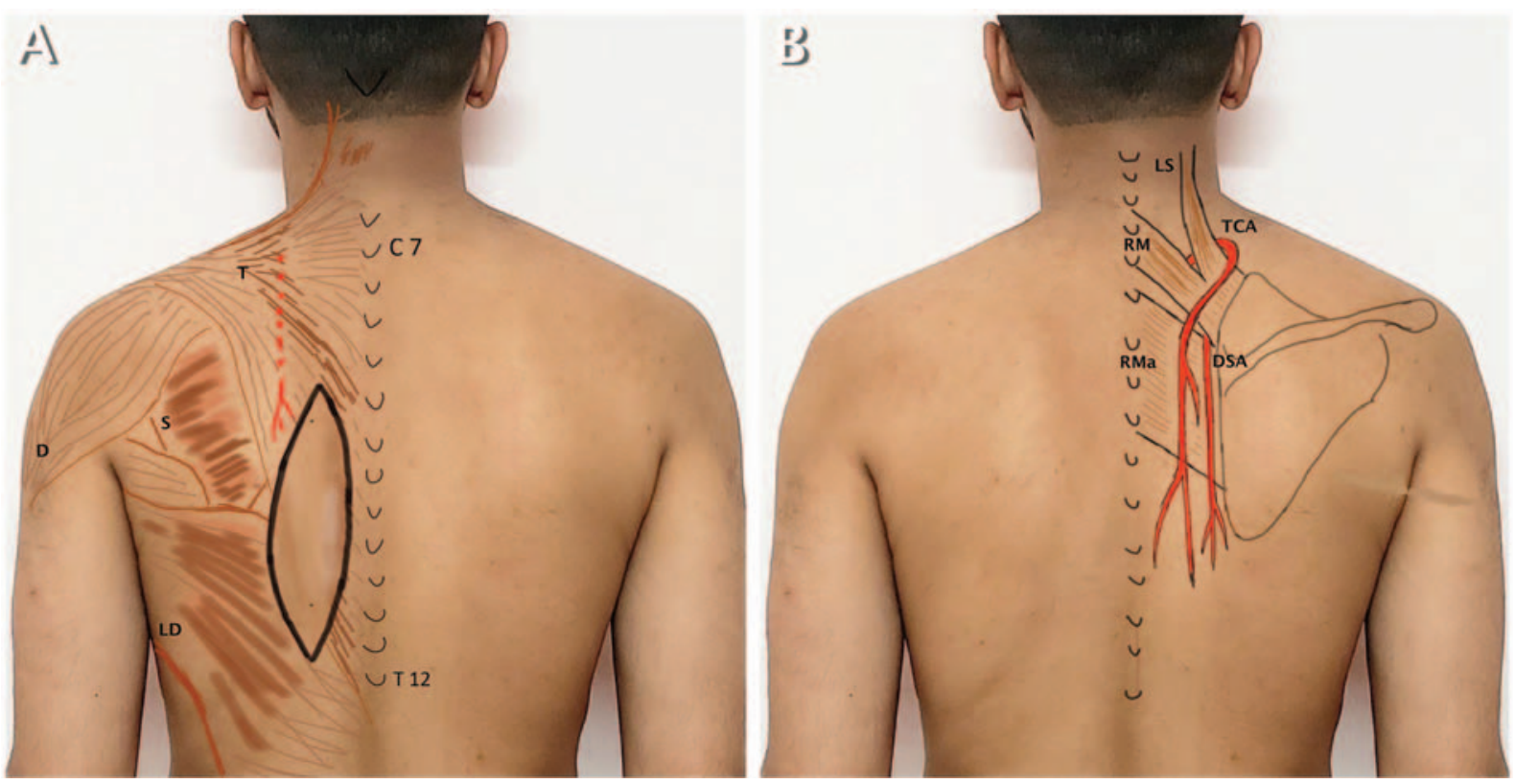

Fig. 1 (A) Image showing important landmarks for trapezius myocutaneous flap: external occipital protuberance, C7 and T12 spinous process. (B) Structures beneath the trapezius muscle. D, deltoid muscle; DSA, dorsal scapular artery; LD, latissimus dorsi muscle; LS, levator scapulae; RM, rhomboid minor; RMa, rhomboid major; S, scapula; T, trapezius muscle; TCA, transverse cervical artery (it is embedded in the ventral surface of the trapezius muscle).

- V-Y advancement flap: this flap is similar to the LTMIF. The skin paddle is designed over the trapezius muscle and the trapezius divided from its attachments while preserving the transverse cervical vessels. In this manner, this flap is useful to cover the soft tissue defects over the upper thoracic region.

- Bipedicled trapezius myocutaneous flap: this flap is similar to the LTMIF. The flap is based on transverse cervical vessels, and the skin in undivided superiorly and inferiorly as in traditional bipedicled flap. The flap is harvested in a bucket-handle fashion and can cover the entire thoracic spine.

\section{Results}

Six patients (three males and three females) underwent seven reconstruction using trapezius flaps (patient 6 underwent reconstruction using a bilateral trapezius flap). The trapezius flap was used to resurface the parieto-occipital $(n=2)$, cervico-occipital $(n=2)$, cervicothoracic $(n=1)$, and thoracic $(n=1)$ regions. The details of the patients are tabulated in - Table 1. One patient (patient 4) had developed postoperative wound dehiscence leading to exposure of the calvarial bone graft. This patient had a fungating calvarial tumor and poor general status and was planned for a flap advancement/implant revision subsequently. Another patient (patient 5) had partial skin graft loss, which healed by secondary intention. Rest of the patients had uncomplicated recovery and stable wound coverage. The mean flap surface area was $110 \mathrm{~cm}^{2}$ (range: $32-240 \mathrm{~cm}^{2}$ ). In five of six patients, donor site was closed primarily, and one patient required skin grafting and latissimus dorsi $\mathrm{V}$-Y advancement flap to cover the flap donor site. Two patients (patients 3 and 5) underwent muscle-only flap and skin graft covering. None of the patients had donor-site seroma or wound dehiscence. Mild shoulder weakness was noted in two patients, which gradually improved with physiotherapy.

\section{Clinical Examples}

\section{Patient 2}

A 20-year-old female patient underwent excision of a C3-C4 spinal intradural extrameningeal meningioma and C2-C5 laminoplasty by the neurosurgeons. Postoperatively, she developed wound dehiscence leading to a wound of $12 \times 9 \mathrm{~cm}$ over the right cervical-occipital region. The implant was exposed, and the cervical spine was exposed at the floor of the ulcer. The patient underwent debridement of the wound followed by reconstruction with right sided LTMIF. The Flap settled well and yielded a good outcome ( - Fig. 2 ).

\section{Patient 4}

A30-year-old female presented with fungating calvarial tumor with intracranial extension. The neurosurgeons performed a palliative resection of the tumor. This resulted in a composite defect of scalp and calvarium in the parieto-occipital region. The calvarial defect was reconstructed with a polymethyl methacrylate (PMMA) prosthesis. The scalp defect was $17 \times 10 \mathrm{~cm}$. The topmost point of the defect was the vertex. Right LTMIF was used to cover the defect. The patient had wound dehiscence leading to the exposure of the PMMA implant. She requires flap advancement or implant revision subsequently (-Fig. 3 ).

\section{Patient 5}

A 15-year-old male patient underwent wide local excision of the rhabdomyosarcoma of the lower cervical and upper thoracic regions, leading to exposure of the spinous processes. 

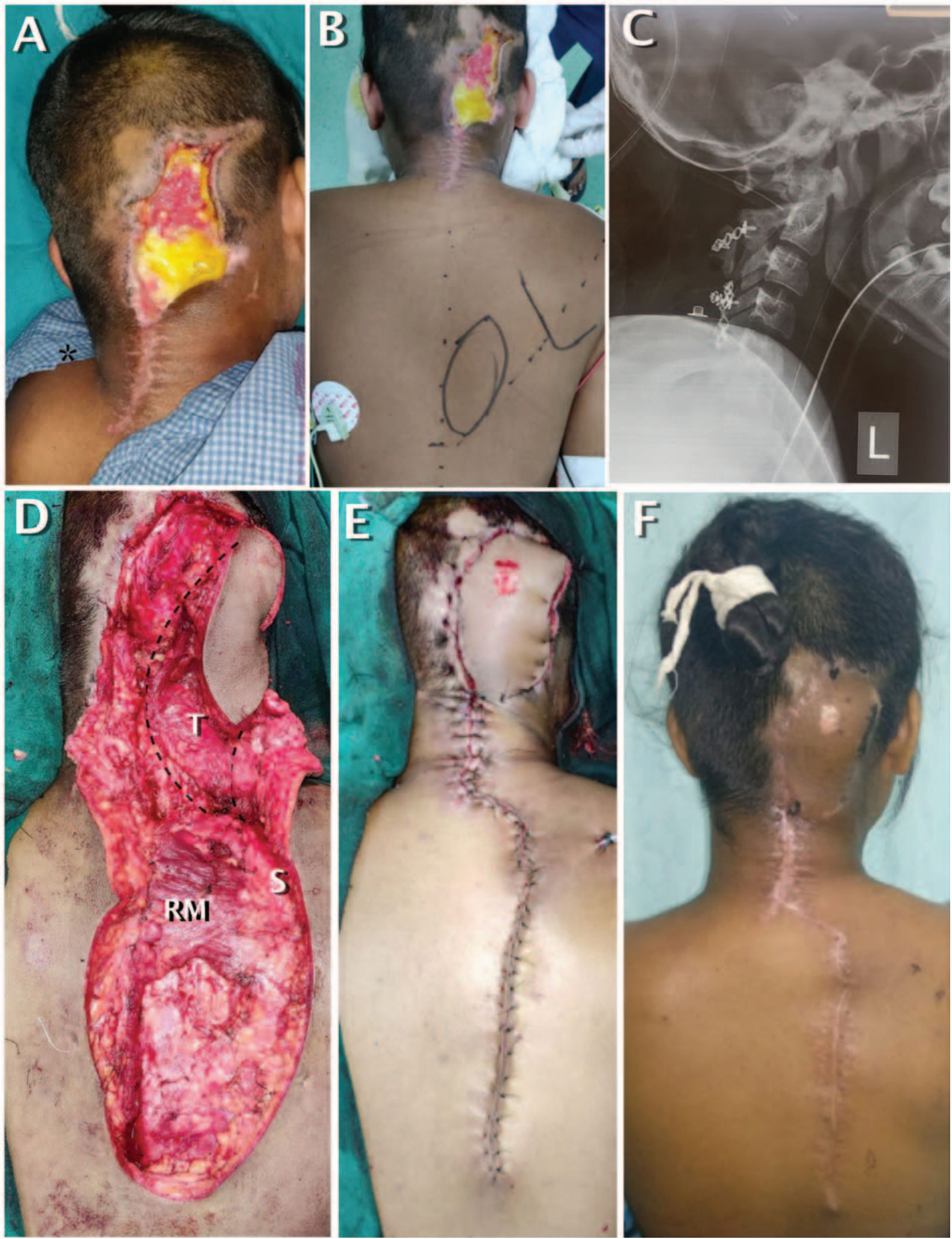

Fig. 2 Image showing (A) soft tissue defect over the right occipitocervical region, (B) flap marking, (C) lateral spine X-ray to show the laminoplasty implants, (D) harvested lower trapezius myocutaneous flap (dashed lines indicate the muscle outline), (E) flap inset and donor-site wound closure, and (F) well-settled flap. RM, rhomboid minor; S, scapula; T, trapezius muscle.

He underwent reconstruction using turnover trapezius muscle flap from the right side and skin grafting. The muscle flap was supplied by the intercostal vessels. Postoperatively, there was minimal skin graft loss, which healed with local wound care ( - Fig. 4 ).

\section{Patient 6}

A 10-year-old child presented with surgical site infection and soft tissue loss following kyphoscoliosis correction and spinal instrumentation. After debridement, the wound size was $25 \times 10 \mathrm{~cm}$ with exposed thoracic spine and spinal 

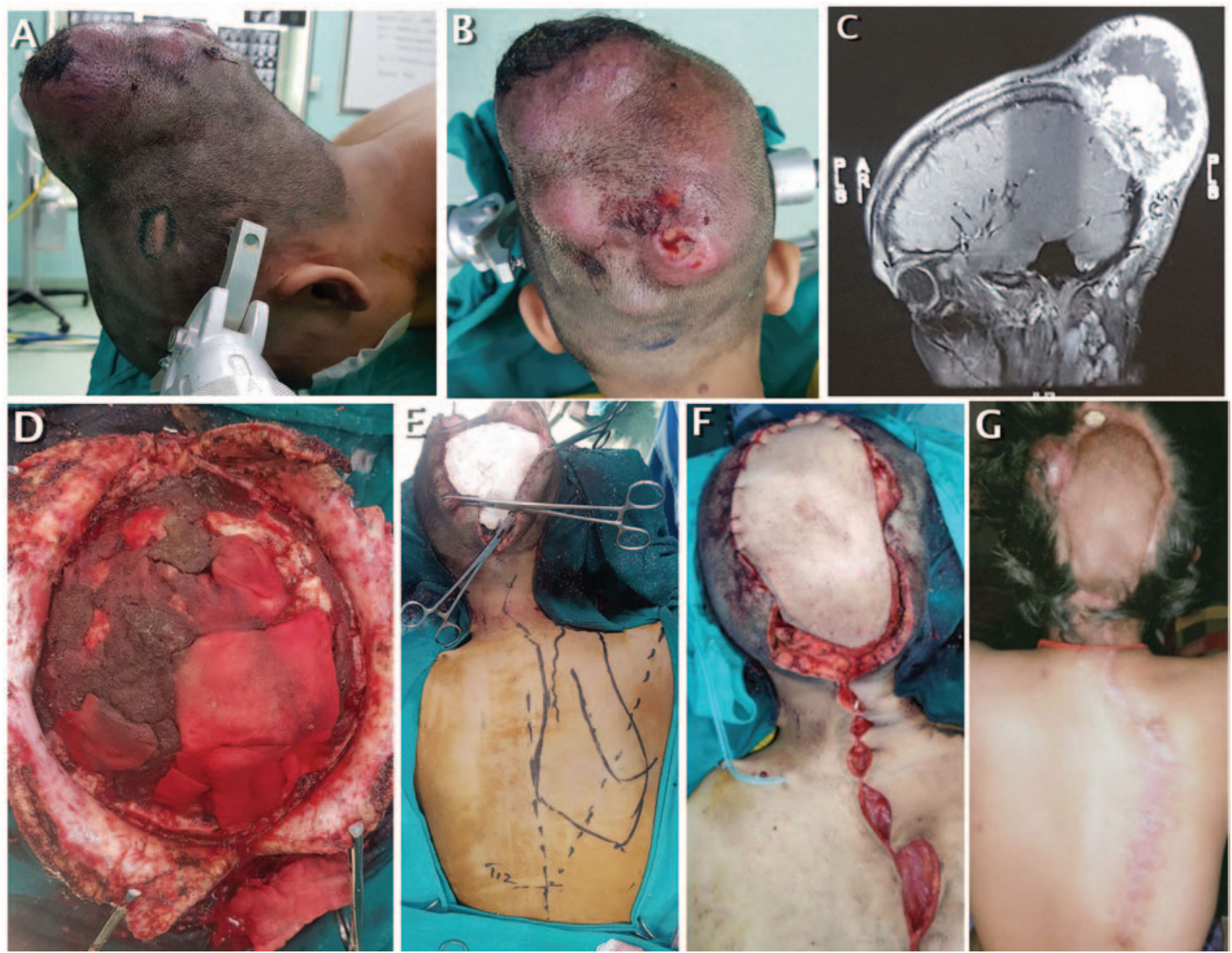

Fig. 3 Image showing (A,B) fungating calvarial tumor, (C) MRI scan showing intracranial extension, (D) duraplasty covered with adrenaline soaked gauze, (E) the calvarium reconstructed with PMMA implant and in situ marking for the right trapezius myocutaneous flap, (F) flap inset, and $(\mathbf{G})$ well-settled flap with minor wound dehiscence. PMMA, polymethyl methacrylate.

instrumentation. Paraspinal muscles were sloughed off and unavailable for reuse. Though a free flap would be an ideal choice, it was kept as a last resort. In $\boldsymbol{- F i g}$. 5C, the skin markings show the outline of the trapezius muscle, and the dotted line on the right side show the markings of the bipedicled flap. The trapezius muscle was included in the bipedicled flap till T12, and beyond this, the flap was undermined completely. We noticed that the flap could be advanced $8 \mathrm{~cm}$ medially at the center point ( $\boldsymbol{- \text { Fig. }}$ 5D). On the left side, a trapezius myocutaneous flap was designed in a $\mathrm{V}-\mathrm{Y}$ fashion, and the muscle was dissected free on the lower, medial, and lateral sides, retaining its blood supply from the upper aspect. The secondary defect that was created by bipedicled flap was covered with a latissimus dorsi myocutaneous V-Y advancement flap. The donor-site defect in the inferior aspect was covered with a skin graft ( - Fig. 5G). Patient's wounds healed completely ( - Fig. $5 \mathbf{H})$.

\section{Discussion}

Wound complications following complex cervico-occipital surgeries are rare and pose a serious reconstructive challenge. This is often complicated by exposure of the underlying bone, dura, and hardware. Compromised blood supply at the incision site is one of the common causes for the wound breakdown. ${ }^{1}$

Secondary intention and split-thickness skin grafting for wound healing are good options for small defects without an exposure of critical structures. In case of large three-dimensional wounds, exposed implants used for the stabilization of craniovertebral junction/cervicothoracic spine, and exposed bone and intracranial structures, flap cover is mandatory. Though local scalp flap options are available, they are useful in small tissue defects only due to their restricted tissue mobility and limited thickness. ${ }^{4}$ Large three-dimensional defects usually require bulky distant flaps or free flaps to provide adequately vascularized soft tissue. Free tissue transfer is a versatile option for the coverage of these defects. However, morbidity might be increased. ${ }^{5}$ Trapezius flap being a regional option is a simpler alternative.

According to Haas and Weiglein, ${ }^{6}$ trapezius flaps can be harvested in four different ways ( - Table 2 ).

In our series, all of the myocutaneous flaps were vertical skin paddle trapezius flaps (LTMIF) when utilized for posterior scalp and cervico-occipital region (type 2) based on the descending branch of the transverse cervical vessels. Dorsal scapular vessels were not included in any of the patients. 


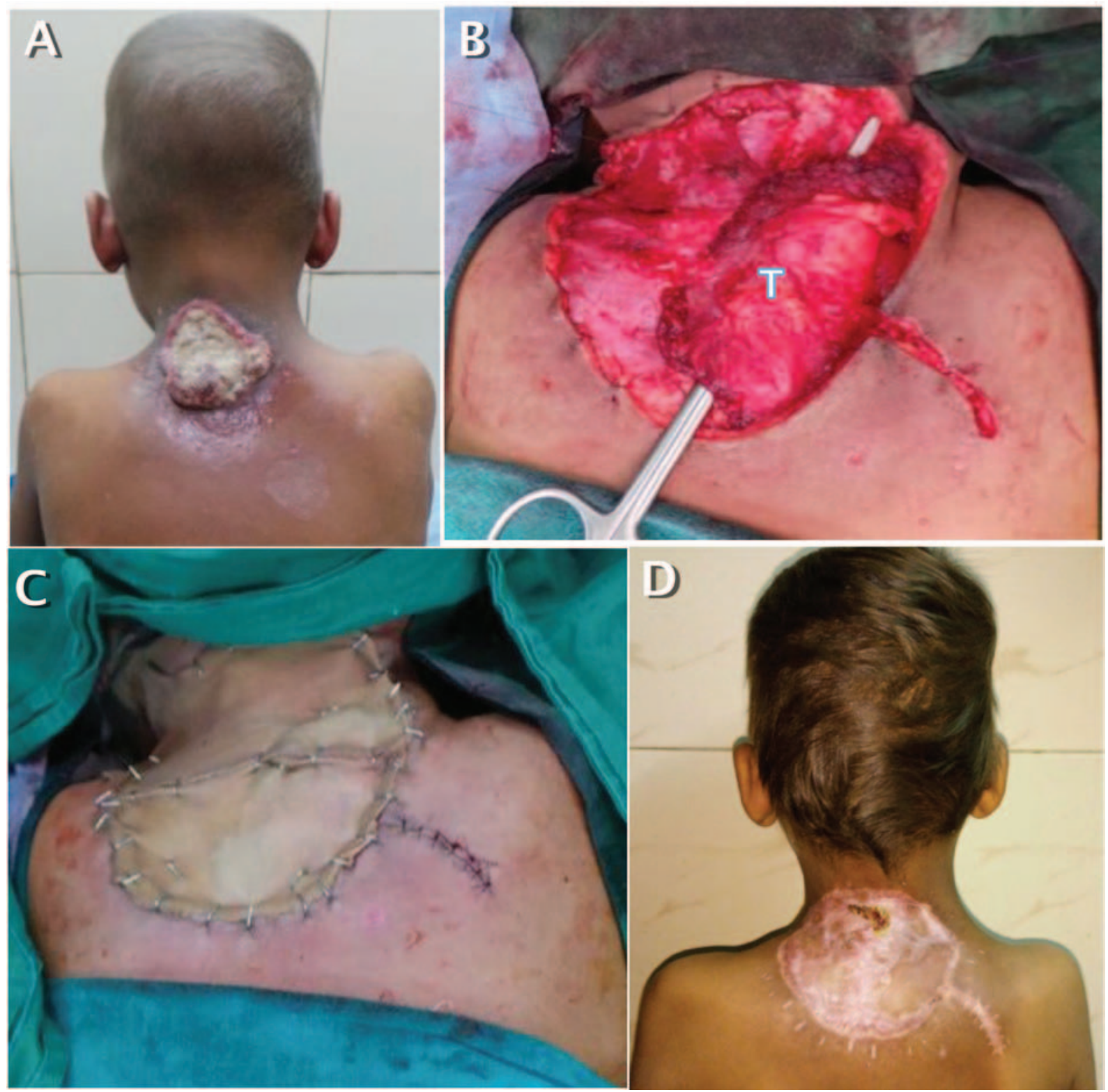

Fig. 4 Image showing (A) rhabdomyosarcoma over the lower cervical and upper thoracic regions, (B) right trapezius muscle flap covering the spinous processes, (C) skin graft over the muscle flap and adjacent soft tissue defect, and (D) well-settled wound.

In all of the LTMIF patients, the lowermost portion of the flap crossed the tip of the scapula by around $<5 \mathrm{~cm}$. It was ensured that more than two-thirds of the skin paddle of the flap was overlying the trapezius muscle. It is well known that the dorsal scapular vessels supply the lower portion of the trapezius muscle and skin predominantly. Skin paddle as low as 10 to $13 \mathrm{~cm}$ below the scapula tip has been described (extended vertical flap design). ${ }^{7}$ Urken et $\mathrm{al}^{8}$ opined that the lower extent of the flap should not be $>5 \mathrm{~cm}$ below the tip of the scapula when the flap is based exclusively on the transverse cervical vessels. Uğurlu et $\mathrm{al}^{7}$ described that the lower border of the skin paddle could be harvested as low as $24 \mathrm{~cm}$ below the tip of the scapula in spite of transecting the dorsal scapular vessels. Can et al included both the transverse cervical vessels and dorsal scapular vessels in the flap and achieved good results. ${ }^{9}$ We also feel that the exclusion of dorsal scapular vessels in the flap design would not affect the flap survival even in the lower vertical trapezius flap.

The mean flap surface area of the largest trapezius flap described was of $504 \mathrm{~cm}^{2} .{ }^{10}$ Preservation of the superior fibers of the trapezius is essential to preserve the function of the muscle. The reach of the flap can be increased by dividing the superior fibers and dissecting the transverse cervical vessels until the origin. However, this can be avoided by using an extended vertical trapezius flap described by Uğurlu et al. ${ }^{7}$ We did not need to cut the superior fibers of the trapezius muscle in any of our patients.

Pedicled latissimus dorsi muscle flap is an option for the coverage of the occipital region. However, it requires extensive dissection and division of the insertion from the humerus and skeletonization of the pedicle. ${ }^{11}$ Trapezius flap is a reliable option for the coverage of the upper thoracic 

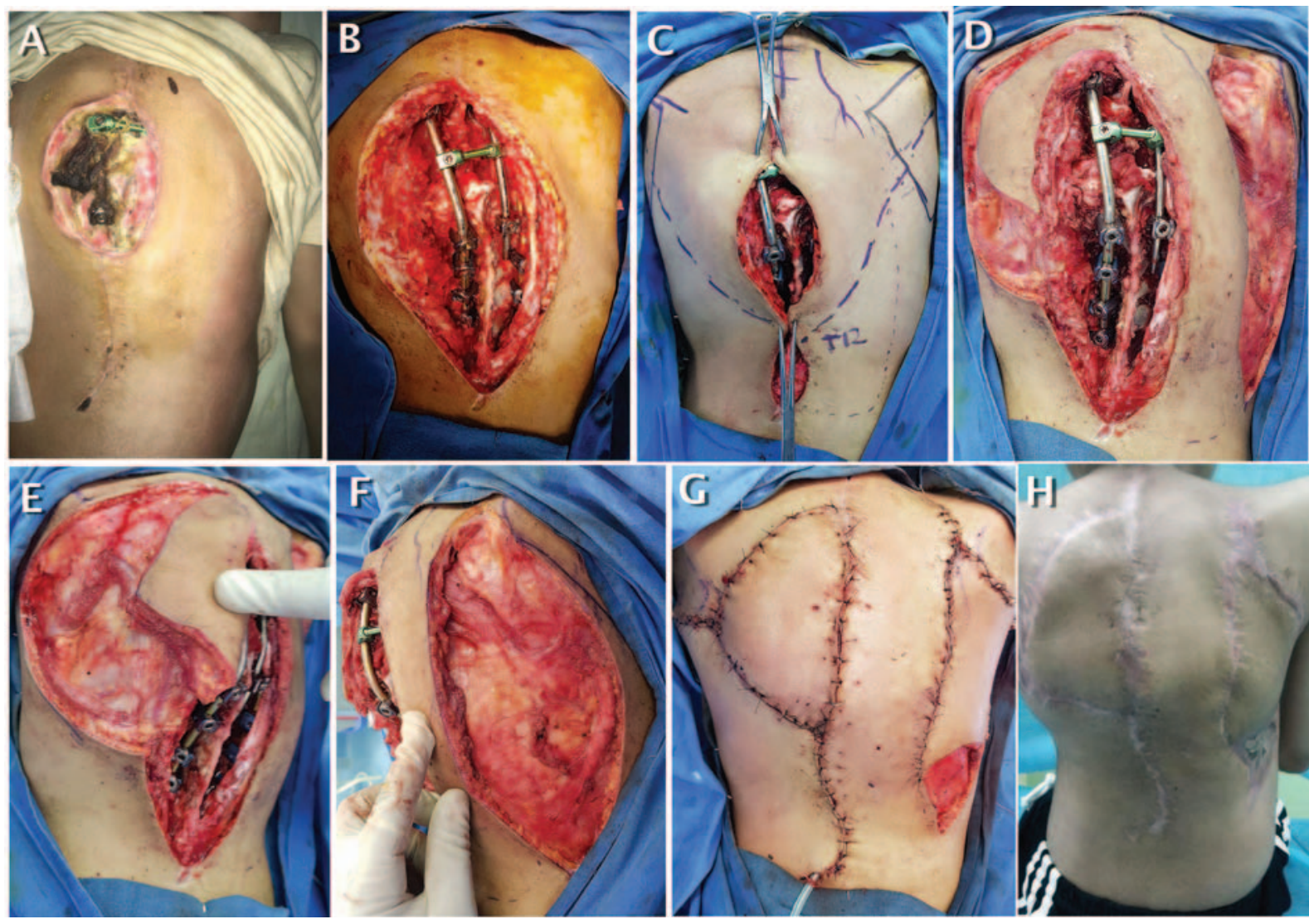

Fig. 5 Image showing (A) ulcer over the back with slough exposed thoracic spinal implant, (B) spinal implant and thoraco-lumbar spine, (C) markings of the trapezius flap on both sides, (D) left trapezius myocutaneous V-Y advancement flap and right bipedicled trapezius myocutaneous flap, (E) advancement of left trapezius myocutaneous $V-Y$ flap, (F) advancement of the right bipedicled trapezius myocutaneous flap, (G) final wound closure after closing the secondary defect with V-Y latissimus dorsi flap on the right side, and (H) well-settled flaps and skin graft.

Table 2 Various types of trapezius flaps

\begin{tabular}{|l|l|l|l|l|}
\hline Type & Blood supply & Muscle & $\begin{array}{l}\text { Skin paddle } \\
\text { orientation }\end{array}$ & Remarks \\
\hline 1 & Occipital vessels & $\begin{array}{l}\text { Superior descending } \\
\text { muscle fibers }\end{array}$ & Transverse & Rarely used \\
\hline 2 & $\begin{array}{l}\text { Ascending and } \\
\text { descending branches } \\
\text { of transverse cervical } \\
\text { vessels }\end{array}$ & $\begin{array}{l}\text { Middle transverse } \\
\text { fibers }\end{array}$ & $\begin{array}{l}\text { Transverse or } \\
\text { vertical }\end{array}$ & Most commonly used \\
\hline 3 & Dorsal scapular vessels & $\begin{array}{l}\text { Inferior ascending } \\
\text { fibers }\end{array}$ & Vertical & $\begin{array}{l}\text { The skin island should overlie the distal border of the } \\
\text { trapezius muscle by at least one-third of its diameter }\end{array}$ \\
\hline 4 & Intercostal vessels & $\begin{array}{l}\text { Ascending muscle } \\
\text { fibers }\end{array}$ & $\begin{array}{l}\text { Turn over muscle } \\
\text { flap (no skin } \\
\text { paddle) }\end{array}$ & $\begin{array}{l}\text { Most commonly used for the middle and upper } \\
\text { thoracic spine }\end{array}$ \\
\hline
\end{tabular}

${ }^{a}$ Other skin paddle designs include a V-Y shape to cover the middle and upper thoracic spine; a bipedicled design is useful for the coverage of long longitudinal narrow defects in the thoracic spine. Both of them are based on the transverse cervical vessels.

Source: adapted from Haas and Weiglein ${ }^{6}$.

spine, ${ }^{12}$ whereas latissimus dorsi muscle flap is used for soft tissue defects over the thoracolumbar and lumbar spine.

Flap survival rate was $100 \%$, and wound gaping requiring resurgery was noted in one $(20 \%)$ patient. Can et $\mathrm{al}^{9}$ reported that $16.3 \%$ of patients required resurgery due to flap-related complications. Literature review shows that complications range from 0 to $57 \%{ }^{9}$

Trapezius flap was also described for the reconstruction of the oral cavity ${ }^{13}$ and face. ${ }^{8}$ The hairless skin suits better for these areas. A limitation of trapezius flap is that it might be compromised in patients with prior neck dissection in which transverse cervical vessels were ligated. Nonhair-bearing skin over the scalp could be a cosmetic concern for some patients. Though uncommon, persistent pain and shoulder weakness might be troublesome donorsite complications.

The limitations of the study are small sample size and shorter follow-up duration. 


\section{Conclusion}

The trapezius flap is a reliable and good alternative option to free flaps for coverage of complex cervical-occipital and upper thoracic soft tissue defects.

\section{Conflict of Interest}

None.

\section{References}

1 Zenga J, Sharon JD, Santiago P, et al. Lower trapezius flap for reconstruction of posterior scalp and neck defects after complex occipital-cervical surgeries. J Neurol Surg B Skull Base 2015;76(5):397-408

2 Chang KP, Lai CH, Chang CH, Lin CL, Lai CS, Lin SD. Free flap options for reconstruction of complicated scalp and calvarial defects: report of a series of cases and literature review. Microsurgery 2010;30(1):13-18

3 Mathes SJ, Stevenson TR. Reconstruction of posterior neck and skull with vertical trapezius musculocutaneous flap. Am J Surg 1988;156(4):248-251

4 Tenna S, Brunetti B, Aveta A, Poccia I, Persichetti P. Scalp reconstruction with superficial temporal artery island flap: clinical experience on 30 consecutive cases. J Plast Reconstr Aesthet Surg 2013;66(5):660-666

5 Boeckx WD, van der Hulst RR, Nanhekhan LV, De Lorenzi F. The role of free flaps in the treatment of persistent scalp osteomyelitis. Neurosurgery 2006;59(1, Suppl 1):ONS64-ONS67, discussion ONS64-ONS67

6 Haas F, Weiglein AH. Trapezius flap. In: Wei FC, Mardini S, eds. Flaps and Reconstructive Surgery Edinburgh: WB Saunders; 2009:249-269

7 Uğurlu K, Ozçelik D, Hüthüt I, Yildiz K, Kilinç L, Baş L. Extended vertical trapezius myocutaneous flap in head and neck reconstruction as a salvage procedure. Plast Reconstr Surg 2004;114(2):339-350

8 Urken ML, Naidu RK, Lawson W, Biller HF. The lower trapezius island musculocutaneous flap revisited. Report of 45 cases and a unifying concept of the vascular supply. Arch Otolaryngol Head Neck Surg 1991;117(5):502-511

9 Can A, Orgill DP, Dietmar Ulrich JO, Mureau MA. The myocutaneous trapezius flap revisited: a treatment algorithm for optimal surgical outcomes based on 43 flap reconstructions. J Plast Reconstr Aesthet Surg 2014;67(12):1669-1679

10 Panje WR. Myocutaneous trapezius flap. Head Neck Surg 1980;2(3):206-212

11 Jeong WS, Roh JL, Kim EK. Extensive scalp reconstruction after repeated failure of free tissue transfer with a pedicled latissimus dorsi flap. J Craniofac Surg 2014;25(3):1103-1105

12 Ndayishimiye JM, Husson JL, Watier E. Reconstruction of extensive posterior mid-thoracic soft-tissue defects after spinal surgery on irradiated skin. Orthop Traumatol Surg Res 2009;95(4, Suppl 1):S35-S40

13 Gal TJ, Jones KA, Valentino J. Reconstruction of the through-and-through oral cavity defect with the fibula free flap. Otolaryngol Head Neck Surg 2009;140(4):519-525 